\title{
Wage Growth Puzzle and Capacity Utilization
}

\author{
Arto Kovanen \\ Correspondence: Arto Kovanen, Principal, Kovanen Macroeconomic Policy Advising, Alexandria, VA, USA. \\ E-mail: arto.t.kovanen@gmail.com
}

Received: December 18, 2018

Accepted: January 15, 2019

Available online: January 22, 2019

doi:10.11114/aef.v6i2.3985

URL: https://doi.org/10.11114/aef.v6i2.3985

\begin{abstract}
Wage growth and consumer price inflation in the United States remain weak, despite robust labor market and a healthy economy. This has been a conundrum for policymakers and economists alike, albeit it is not without parallels. In this paper, we analyze recent trends in the labor market. We point out that a number of indicators are providing mixed signals about the tight labor market, including wage growth that has remained muted, vacancy duration rates that have stayed remarkable stable in certain sectors, and the rate of capacity utilization, which is cyclically low and out of sync with other measures of resource utilization (e.g., output gap and unemployment rate). This leads us to conclude that there could be other forces that explain these phenomena. In this paper, we focus on capacity utilization and contend that low capacity utilization rates are the outcome of strategic decision-making by corporations, rather than inefficient demand, which permits firms to manage their resources more effectively. It seems to be particularly important when economic and policy uncertainties are elevated, such as in the post-financial crisis environment. More flexible use of capacity has implications not only for the labor market, but also for investments. Understanding capacity utilization would contribute to monetary policy formulation when the signal coming from the rate of capacity utilization is not consistent with those coming from the labor market and the output gap. This points to the need to continue monitor a broad range of indicators to avoid potential policy errors.
\end{abstract}

Keywords: wages, labor market, vacancy duration, capacity utilization, resource management, inflation, monetary policy

JEL Classifications: E23, E22, E24, E3, E52

"The current cyclical upswing is now approaching six years in duration, and the economy has retained considerable vigor, with few signs of imbalances and inflationary tensions that have disrupted past expansions" [Alan Greenspan (1997)].

\section{Introduction}

Economists and policymakers have continued to struggle with the predicament that tight labor market and healthy economic growth have not generated faster wage growth and inflation. Hourly earnings growth has averaged around 2.5 percent annual rate since the crisis (Note 1). Inflation, using the Personal Consumption Expenditure (PCE) price index, has only recently reached the policymaker's 2 percent target. Furthermore, market-based measurements of inflation compensations have remained stable and survey-based inflation expectations are little changed (Note 2).

However, the current situation is not necessarily without parallels. Former Federal Reserve Chairman, Alan Greenspan, raised similar concerns in his testimony before Senate Committee on the budget some 20 years ago (the above quotation is from this testimony; Greenspan, 1997). Similar to the current situation facing the U.S. economy, the official unemployment rate (i.e., total unemployed as a percent of total civilian labor force or U-3) in 1997 was low, at about 51/4 percent, which was widely considered consistent with full employment (based on the estimated non-accelerating inflation rate of unemployment or NAIRU). The unemployment rate was also below its cyclical low during the previous upswing, achieved in late 1980s. On the other hand, the rate of capacity utilization was high, which signaled that the economy was operating at a high level of resource utilization consistent with other measures of resource utilization (including the position of actual output to its potential). In light of this backdrop, Chairman Greenspan noted, quite appropriately, his surprise that "in contrast to earlier periods, we have not experienced a broad increase in inflation" (Note 3). He observed that economic events are never wholly random and empirical regularities in behavioral relationships could be followed with some degree of confidence, although each business cycle has its own characteristics. Greenspan also noted that the sluggish wage growth was associated with rising profitability and high rates of return on 
capital, which he viewed as indicative of competitive pressures that limited companies' ability to raise wages and prices.

In this paper, we analyze recent trends in the U.S. labor market and point out that a number of indicators are sending mixed signals about the tight labor market, including wage growth that has remained muted, vacancy duration rates that have stayed remarkable stable in certain sectors, and the rate of capacity utilization, which is cyclically and historically low and out of sync with other measures of resource utilization (e.g., output gap and unemployment rate). This leads us to conclude that there could be other forces in play to explain these phenomena. We focus on capacity utilization to better understand labor market developments and the wage growth puzzle, which has probably received too little attention in the literature, and in this context we reference relevant literature. Research indicates that low capacity utilization rates are the result of strategic decision-making by corporations that permits them to manage their inputs more effectively. It seems to be particularly important when economic and policy uncertainties are elevated, such as in the current post-financial crisis environment. Capacity utilization has implications for inflation, which was closely studies during the 1990s but a renewed interest in this relationship seems appropriate. More flexible use of capacity has consequences for investments, which are likely to be uneven and timed to create buffers against unexpected shocks. Monetary policy would also benefit from a better understanding about capacity utilization and resource constraints. Daly and Hobjin (2017), for instance, have analyzed substitution between higher paid and lower paid employees to explain current wage pressures (Note 4). We think that new technology has changed the way labor is hired and used in the production of goods and services, which will have profound implications for the labor market and resource management and would complement other explanations for muted wage pressures. The adoption of new production technologies permits companies to manage resources more flexibly in response to cost and demand shocks. This does not apply evenly to all companies and all industries, as capital-intensive industries, for instance manufacturing and large enterprises, are better positioned to exploit such flexibility. On the other hand, enterprises in service-providing, labor intensive and less capital-intensive sectors, and small-scale enterprises, seem to experience larger obstacles because their primary input (labor) cannot be easily substituted for other inputs. The paper has been organized as follows: Section 2 reviews the main trends in the U.S. labor market and highlights some indicators that appear to send mixed signals about the labor market tightness. In Section 3, we introduce capacity utilization as a strategic component in the corporations' decision-making, which would assist firms in managing their resources and alleviate cost and demand pressures. This is increasingly facilitated by evolving technology that is changing the way resources are contracted and utilized in the production. Section 4 discussed the likely challenges facing policymakers in formulating monetary policy in the current environment where information on the capacity utilization rate points to a much larger resource slack than other indicators used to measure the economy's resource constrains. Section 5 concludes.

\section{Understanding Labor Market Trends}

Economists generally agree that the U.S. economy has reached full employment, as unemployment by a variety of measures is close to all-time lows (Figure 1). The official unemployment rate, using the U-3 measure, fell to 3.7 percent in November 2018. Unemployment rate has been this low only three times since the 1950s: 2.5 percent during MayJune 1953, 3.4 percent from September 1968 to April 1969, and 3.8 percent in April 2000 (Note 5). Current unemployment rate is also below the low reached during the previous business cycle.

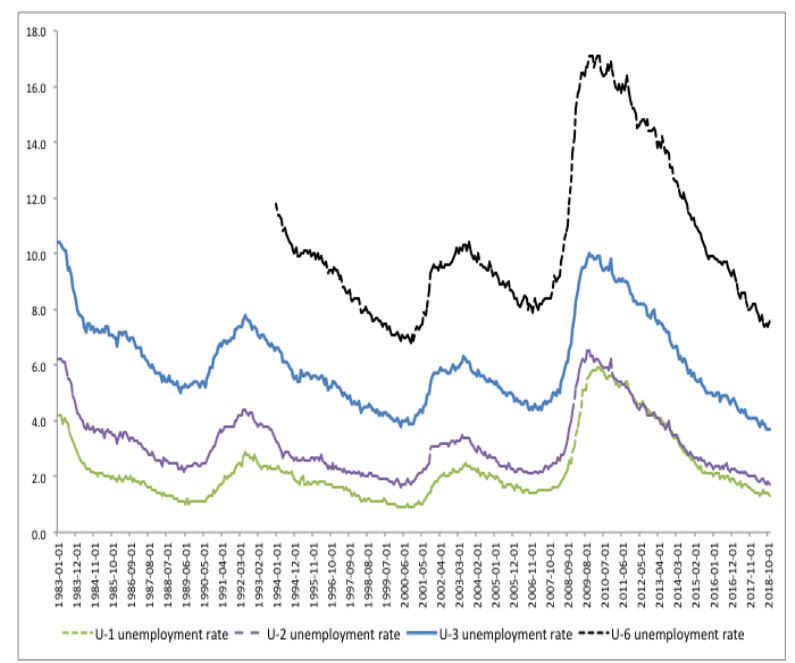

Figure 1. Selected unemployment rates (1983M1 - 2018M11; in percent)

Sources: Federal Reserve Bank of St. Louis and the author. 
The widest measure of labor underutilization (U-6) includes marginally attached unemployed and individuals employed part time for economic reasons, which many consider to be a more accurate metric of the slack in the labor market. It fell to 7.6 percent in November 2018, which is below its low during the previous business cycle (Note 6). Official unemployment is below the NAIRU, which the Congressional Budget Office estimates at 4.6 percent for the fourth quarter of 2018 (using U-3 measure). The unemployment rate gap (the difference between actual and NAIRU) has been negative for 6 consecutive quarters and has averaged half of a percent. However, this is not necessarily unheard of, as in the second half of the 1990s unemployment rate remained below the natural rate for 16 quarters, and the unemployment rate gap averaged -0.9 percent without leading to accelerating inflation pressures (Kovanen, 2019) (Note 7).

The signal provided by the unemployment rate is consistent with the output gap (i.e., the difference between actual and potential output), which also indicates that U.S. economy has reached full employment. Output growth is currently estimated to be above the potential level. As Figure 2 illustrates, unemployment rate and output gap have moved in tandem since the financial crisis. This close relationship between the rate of unemployment and real output was originally penned down by Okun (1962), which became known as the Okun's Law because of its consistency in the data. Using the gap version of the Okun's Law, output gap is used to explain movements in the unemployment. More recently, Knotek (2007), among others, has evaluated the stability of the output gap coefficient in the Okun's Law and shows that the coefficient has fluctuated in a relatively narrow range $(0.5$ to 0.7$)$ since the $1990 \mathrm{~s}$. This suggests that unemployment rate would be about half a percent above the full employment level for each one percent shortfall in real output from the potential. Further evidence of tightness in the labor market is provided by the vacancy-to-unemployment ratio. Data show that since the financial crisis the number of vacancies to unemployed has risen from roughly 1-to-7 (i.e., for each vacancy there was seven unemployed) in mid-2009 to about 1-to-1 ratio as of April 2018 (latest available data).

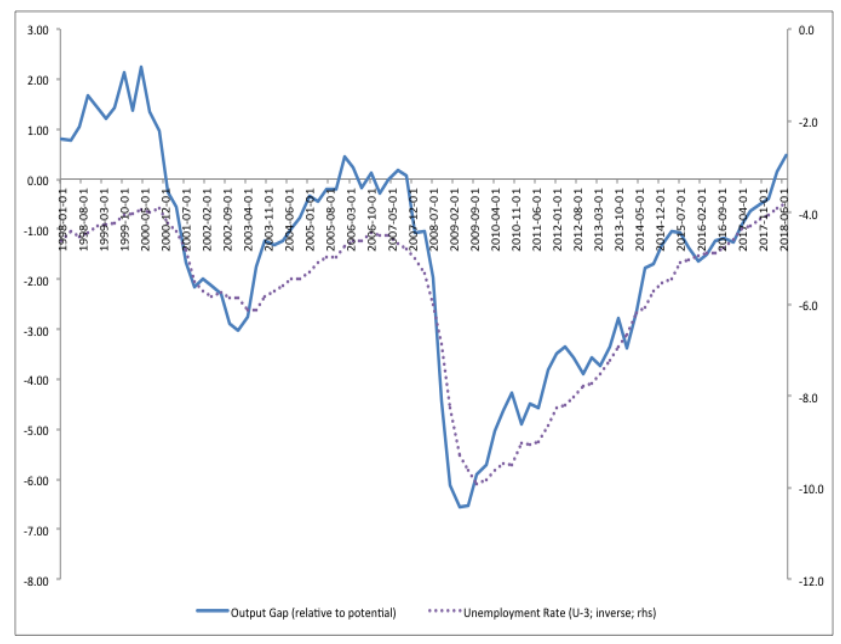

Figure 2. Unemployment rate and output gap 1998Q1 - 2018Q3

Sources: Federal Reserve Bank of St. Louis and the author.

However, employment growth has not been shared evenly across all economic sectors. While service-providing industries have added 17 million jobs since 2009, employment in goods-producing industries has only risen by 3 million during the same period. Total employment in the goods-producing industries (i.e., mining, oil and gas extraction, logging, construction, and manufacturing) still remains below the 25 million recorded in 2000 . Of these, manufacturing is largest of the goods-producing sectors, but has only created about 1 million jobs since 2009, and employment in this sector remains only about one-half of the level recorded in the late 1970s. This illustrates a secular decline in the manufacturing sector, affected in part by outsourcing and automation, which currently accounts only about 15 percent of total civilian employment. The service sector represents 70 percent of the total nonfarm payroll in the U.S where the largest employers can be found in whole and retail trade, education and health, professional and business services, and leisure and hospitality industries. The public sector, which comprises federal, state and local governments, has not been a significant job creator since the latest recovery begun.

\subsection{Alternative Measures of Resource Availability}

Despite the strong economy, capacity utilization has remained well below its cyclical highs. It conflicts with other metrics, such as the NAIRU and output gap and points to the need to understand how to interpret the signal coming from capacity utilization for measuring economy's resource constraints. The rate of capacity utilization has stayed remarkably stable during the past 6 years despite tightening labor market while the economy has reached its potential using other indicators. Among other things, this has important implications for monetary policy that typically relies on 
alternative gap measures for assessing the resources constraints and their implications for inflation, and underscores the challenges in accurately estimating the resource constraints (e.g., the Taylor rule uses either output or unemployment gap to measure activity level against benchmark that is expected to be consistent with price stability).

Furthermore, in spite of the labor market tightness and low unemployment, wage and price pressures have remained muted. This is inconsistent with the Phillips curve, which predicts that low unemployment would lead to rising wages and inflation. When the economy is operating at a level above its capacity (or potential), marginal cost of producing output with existing capacity would increase (i.e., companies are operating on the upward-sloping part of the marginal cost curve). That would lead to price increases as companies would shift higher operating costs to the consumers. Recent evidence, however, suggests that the slope of the Phillips curve in the United States is almost flat while the relationship between unemployment and wages has become less accurate. See Staiger, Stock and Watson (2001), Leduc and Wilson (2017), and Murphy (2018). When the rate of unemployment has been low in the past, wage growth has almost invariable accelerated to more than 4 percent annual rate. This has not materialized during the current recovery. Despite low and falling unemployment, wage growth, measured by the year-on-year change in hourly earnings, has averaged below $2 \frac{1}{2}$ percent since the recovery started, leading to a widening gap between the rate of unemployment and wage growth (Figure 3). While earnings growth has accelerate in recent months, it still remains modest by historical standards (in November 2018 hourly earnings grew 3.1 percent annual rate).

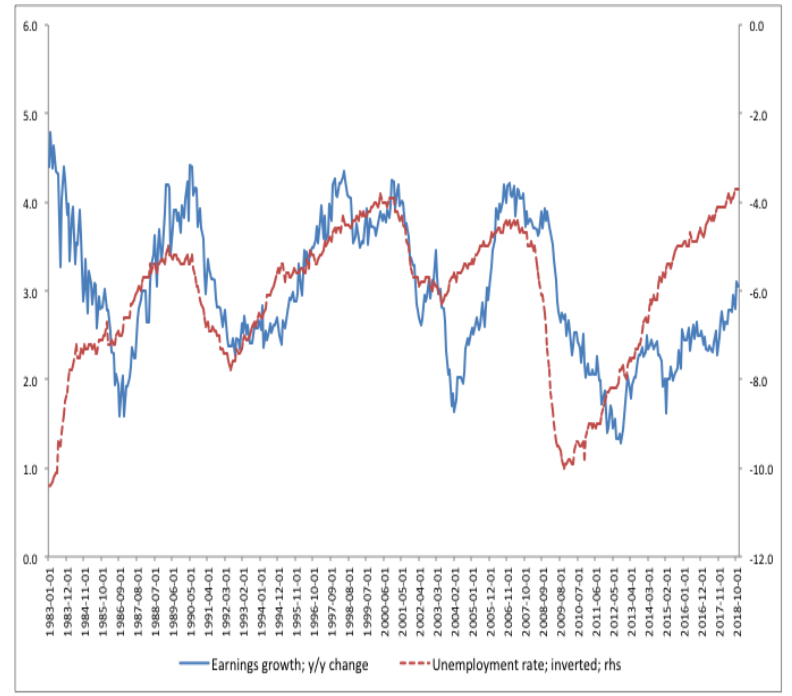

Figure 3. Hourly earnings growth and unemployment rate (1983M1-2018M11; in percent)

Sources: Federal Reserve Bank of St. Louis and the author.

Developments in the first half of the 1990s offer an interesting parallel. From April 1992 to March 1995, wage growth during this period averaged 2.5 percent although unemployment rate fell from 7.4 percent to 5.4 percent. Ravenna and Walsh (2008) show that the elasticity of inflation to changes in the unemployment rate also depends on structural characteristics of the labor market, including technology that pairs vacancies with unemployed workers. See Ghayad and Dickens (2012), and Erenburg (1998) who shows that real wages tend to behave counter-cyclically, which is consistent with diminishing returns to labor, while capacity utilization is pro-cyclical relative to real wages.

A number of factors could explain the observed restrain in nominal wages during the current recovery. Flattening of the Phillips curve has been observed in a number of industrial countries, which reduces the responsiveness of wages to labor market imbalances (see, for instance, Bean (2006) and IMF (2006)). Due to an increase in global competition, corporations are likely to have less scope to increase product prices. Furthermore, because of the global demand for goods and services, changes in domestic demand may have less influence on prices (a good portion of U.S. corporations' revenue comes from sales outside the U.S.). Central banks have also succeeded in anchoring inflation expectations to a low rate of inflation, which could have reduced sensitive of consumer prices in response to shocks affecting the economy (due to credible nominal anchor). Inflation has averaged 11/4 percent per year in the period following the financial crisis. When taking inflation into account, inflation-adjusted hourly earnings during the current recovery are some 10 percent higher than before the crisis, which is not insignificant and it is comparable with the increase in inflation-adjusted hourly earnings during the 1990s recovery (Kovanen, 2019). 


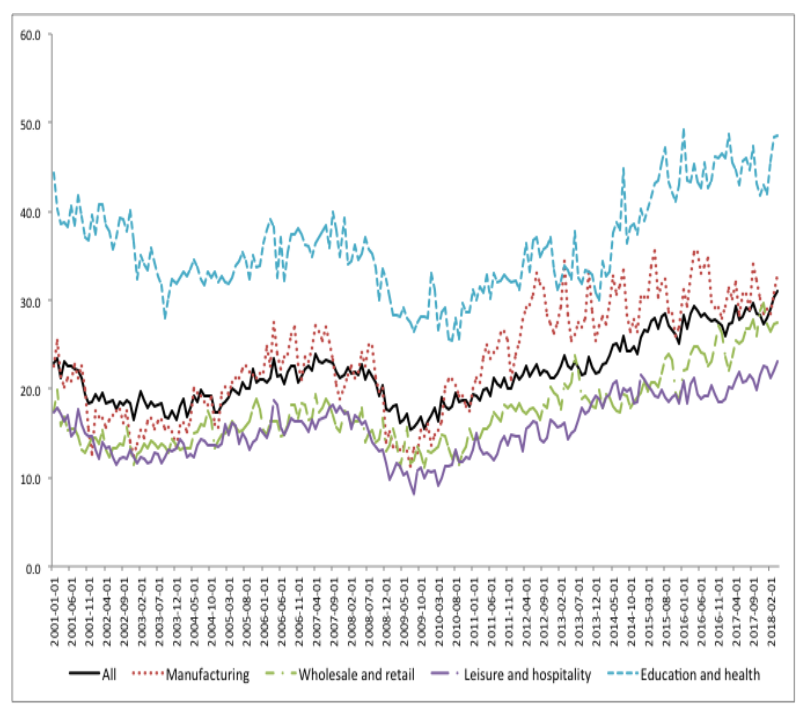

Figure 4. Mean vacancy duration by economic sector (2001M1-2018M4; working days)

Sources: DHI-DFH Mean Vacancy Duration Measures; retrieved from the Federal Reserve Bank of St. Louis and the author. Furthermore, data on vacancy durations show that the "tightness" for labor varies significantly across sectors and companies. As shown in Figure 4, some sectors appear more capable in managing their hiring than others, although mean durations to fill a job vacancy have risen in all sectors of the economy. For the labor market as a whole, mean duration has increased from the trough of 15 working days in 2009 to about 31 working days in April 2018 (latest available data). Vacancy durations are highest in the education and health service sectors, averaging 48 working days in April 2018, followed by financial services (where it is 45 working days) (Note 8). This might indicate that there are non-price factors, such as the shortages of qualified workers in these sectors, which complicate the hiring process. In wholesale and retail services, as well as in leisure and hospitality, vacancy durations are below the average for the U.S. economy (but above their previous highs), which could point to lower entry requirements in these sectors, making it easier to find new employees (Note 9).

However, in manufacturing vacancy duration rates have not risen since 2012 and have fluctuated at around 30 working days (this is above the pre-crisis highs). This is somewhat unexpected given the tightness of the U.S. labor market. While it is possible that this may have been caused by sluggish output growth, it could also indicate that manufacturing companies have, by and large, capacity to manage their hiring more effectively and with new technology have been able to increase flexibility in labor use in the production. Differences between mean vacancy durations across industries have not translated into consistent deviations in earnings growth. For instance, hourly earnings growth in education and health service industries has not been significantly higher than the average for service-providing industries, which might point to limitations facing firms that engage in cost-based measures to attract new workers. In manufacturing, wage growth has remained below the economy-wide average.

Importantly, mean vacancy durations vary by the size of the worker pool. This suggests that company size matters for the ability to manage the hiring process. In general, companies that have sizeable worker pools tend to spend more time in filling vacancies than smaller enterprises (Figure 5). On average, it takes 57 working days for large companies to fill a vacant position (i.e., companies employing 5 thousand or more workers). This is twice as long as for companies that employs less than 250 workers. Differences in hiring durations are not entirely due to the tight labor market, but also reflect differences in the way companies plan hiring (larger companies have more "complex" hiring processes than their smaller counterparts and tend to take longer to fill vacancies). The longer-term trends in the time series provide some indication about the impact of labor market conditions on vacancy durations, which are elevated, on average, and consistent with the declining rate of unemployment. At the same time, they have remained remarkably stable since 2012, particularly for larger companies that employ more than thousand workers (i.e., the mean vacancy duration was not higher in 2018 than in 2012, despite substantial tightening in the availability of labor resources). This could point to their ability to manage the labor pool better than smaller companies, which may have contributed to lower wage pressures. For smaller companies vacancy durations have continued to increase (Figure 5), which would underscore the fact that these enterprises are likely to experience more severe challenges in hiring new workers. 


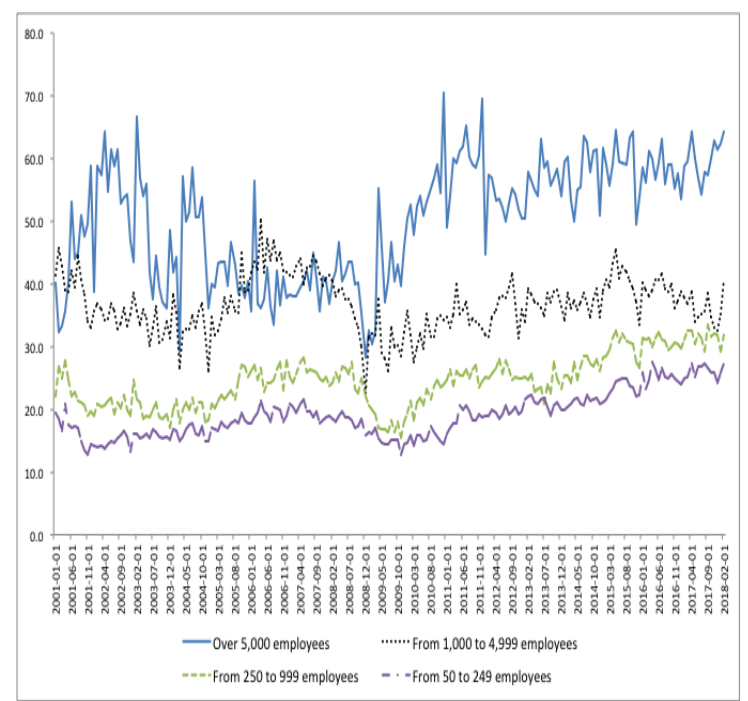

Figure 5. Mean vacancy duration by number of employees (2001M1-2018M2; working days)

Sources: DHI-DFH Mean Vacancy Duration Measures; retrieved from the Federal Reserve Bank of St. Louis and the author.

\subsection{Importance of Substitution and Technological Innovation}

Substitution between higher paid and lower paid employees also seems to have impacted the average wage growth and consequently could help explain the "puzzle" that wages haven't responded adequately to the tightening in labor market conditions. Daly and Hobjin (2017) show that the entry of new and returning employees to full-time employment could reduce wage growth because new entrants often earn less than those who are leaving full-time employment, even if wages of continuously employed full-time workers continues to rise. For similar reasons, as baby boomers exit the labor force and move into retirement, this may also contribute to lower earnings growth. Daly and Hobjin (2016a) distinguish between intensive and extensive margins and show that these influence wage growth. When labor markets are tight, continuously full-time employed workers drive wage growth, but during downturns the pro-cyclicality of the intensive margin is largely offset by net exits out of full-time employment among workers with lower wages. This causes aggregate real wages to be largely unsynchronized with the business cycle. Furthermore, the intensive margin is associated with the wages of continuously full-time employed workers while the extensive margin is associated with the wages of those entering and exiting full-time employment. The relative importance of these margins does not remain constant during the business cycle. Moreover, employment growth has occurred primarily in the service sector where wages and productivity are lower than in the goods-producing sectors, which could introduce downward pressure on hourly earnings. If substitution between high and low wage labor is applied to productivity, it is possible to argue that low productivity growth in the post-financial crisis period could in part be explained by the exit of higher productivity workers who are replaced by lower productivity entrants. However, Kovanen (2019) points out that labor productivity in the aftermath of the financial crisis has not been out of line with earlier recoveries, with the exception of the late 1990s when labor productivity rose significantly. See also Daly, Hobjin and Pyle (2016b).

A number of recent studies focus on changes currently taking place in the labor market due to the adoption of new technologies. Unlike earlier technological innovations, which were typically thought to enable workers to become more productive as technologies complemented their efforts, the emergence of smart robots and other autonomous technology has raised concerns that these would replace workers in the production process and lead to massive unemployment. For instance, Mokyr, Vickers and Ziebarth (2015) alleviate these concerns by adopting a historical perspective to the technological innovation and highlight the different effects that technological change may bring to labor markets over time. They argue that worries about the impact of technology on employment are not new, spanning from the Industrial Revolution to Great Depression. In the short run technological change can be disruptive, leading to unemployment and lower wages, but in the long run innovations could provide substantial benefits to the society in the form of new products and services that did not exist previously. That would create new occupations and lower costs of products and services. The authors conclude that while the predictions of widespread technological unemployment in the past were, by and large, wrong, we should not trivialize the costs borne by the many who are actually displaced. Furthermore, they argue based on historical lessons that technological change is unlikely to lead to a widespread lack of meaningful employment in the long run, but technological change raises important policy issues. Wages of some classes of workers may need to be supplemented through some form of income redistribution and it may be necessary to expand social 
safety nets (food, housing, education and health). Similarly, Dufva et al. (2017) highlight the policy implications of changing content of work from routine tasks to more complicated duties that may require increased interaction between workers. Continuous learning is likely to be part of the future employment picture, in order to improve critical thinking and analytical skills.

Berriman and Hacksworth (2017) estimate that almost 40 percent of U.S. jobs could be at high risk of automation. Sectors most exposed to the impact of automation are those where many routine and repeated tasks would be replaced by automation, which highlights the importance of increased education attainment as a way to reduce the potential risk of automation. However, the net impact of automation on total employment is ambiguous since new technology will also create new jobs, for instance in the digital technology. In addition, through increased productivity there is likely to be new wealth that will support spending growth and add jobs in the service sector. However, benefits may not be evenly distributed across all income groups, which may require government intervention.

Chui, Manyika and Miremadi (2016) show that automation will affect almost all jobs to a degree, including sectors such as healthcare and finance, which traditionally involve substantial share of knowledge work. Consequently, automation could transform the workplace for everyone. In some industries, such as retailing, automation is already changing the nature of competition. For instance, e-commerce competes with traditional retailers by both using physical automation (e.g., robots in warehouses) and the automation of knowledge work (e.g., algorithms that alerts shoppers to items they may want to purchase). This could provide a unique chance to rethink how workers engage with their jobs and how digital labor platforms can better connect individuals, teams and projects. The authors also point out there are factors that could prevent or slow down this process (e.g., the cost of developing and deploying hardware and software for automation, which could be delayed by abundant supply of labor that pressures wages). UBS (2016) study argues that innovation will expand the range of jobs that can be automated from highly repetitive low-skill jobs to also include highly routine medium-skill jobs, which will intensify income inequality between low- and high-skill workers. Benzell et al. (2015) emphasize that the long-term decline in labor income share would have significant implications for ability to consume and save, and ultimately for production if capital is in the hands of few. Guiseppe (2014) points out distortion in statistics from outsourcing, which has moved workers to service sector firms although workers' tasks haven't changed and consequently the observed reduction in manufacturing jobs and the corresponding increase in service sector jobs is partially due to reclassification. See also Frey and Osborne (2013).

Furthermore, Michaels and Graetz, (2015) suggest that increased use of industrial robots has raised labor productivity, total factor productivity and wages, but this has had no significant effect on total hours worked. However, they find that there is some evidence to support the view that robots reduce employment of low skilled labor, and to a lesser extent, middle skilled workers. Brynjolfsson and McAfee (2015) argue that new technology is likely to replace workers by reducing production costs and lowering the prices of goods, and consequently technology can lead to increased demand for goods and production, and increased demand for labor. While the importance of human labor is likely to decline in relevance because of technological progress, the authors do not believe that hardware, software, robots, and artificial intelligence would be able to take over human labor in the short term (e.g., interpersonal and social skills cannot be replaced easily by robots). See Arntz, Gregory, and Zierahn (2016), and Krusell et al. (2000),Violante (2016), and West (2015).

\section{Capacity Utilization in Operations Management}

Businesses consider several factors when deciding how much capacity to employ in the production. Lane and Rosewall (2015), for instance, study firm-level capacity utilization and point out that the assessment typically embodies some consideration of what combination of inputs should be utilized for achieving an optimal, or profit maximizing, outcome. Companies in capital-intensive industries, such as manufacturing, mining, and transport and storage, tend to view available production capacity in terms of both the capital stock and labor, and substitution between them, while in much of the service-providing industries the primarily emphasis is on labor, reflecting relatively low level of capital used by these businesses. Because of differences in the capital intensity, labor market tightness would affect goods-producing industries differently than service-providing industries.

Some earlier studies have attempted to shed light on the role of capacity utilization in production. Bils and Cho (1993) show that cyclical variations in factor utilization help explain observed variations in real activity. Fagnart, Licardro and Sneessens (1995) link changes in the rate of capacity utilization to companies' market power. When demand for goods and services is subject to uncertainty, firms tend to prefer capacity underutilization to costly capital-labor adjustment in response to shocks. Shapiro et al. (1996) suggest that adjustments in the capital utilization are very important in U.S. manufacturing; once variations in capital utilization have been accounted for, little cyclical movements in productivity remain to explain increasing returns to scale or to drive real business cycle models.

More recent research shows that technology alters capacity utilization by increasing flexibility that companies have in managing their resources. A study of Bansak, Morin and Starr (2004) shows how technology could lower the average 
capacity utilization rate if it reduces the cost of holding spare capacity, but it could also increase capacity utilization rates if further changes in capacity become less costly and less time-consuming. On average, the study finds that technological changes in the U.S. have reduced the rates of capacity utilization between 0.2 and 2.3 percentage points. They underscores that a change in capacity utilization may or may not involve a change in the total capacity or technology, which has implication for the cost of production and profitability. Changing output while retaining capacity at the same level enables firms to respond quickly to sudden, temporary changes in demand, but it could raise production costs and therefore it may not be a sustainable strategy when shifts in demand are perceived as permanent. Changing capacity using existing technology involves a fixed cost of adjustment and permits enterprises to maintain a higher level of output on a sustained basis without incurring higher costs. For instance, if a permanent increase in demand is accommodated by higher capacity, the utilization rate would remain constant, after rising initially, reflecting short-term costs of adjustment. Over the longer-term utilization rates return to their previous, pre-adjustment levels. New technology in the production offers an opportunity to expand capacity, but also reduces production costs. Capacity utilization may or may not return to its earlier level, as firms may want to hold more excess capacity than before if doing so will be less costly. Alternatively, firms may hold less excess capacity if technology makes future adjustments in capacity less costly and less time consuming. Jakubovskis (2017) examines different factors that impact capacity utilization and resource flexibility and shows that a higher rate of flexible in the production raises capacity utilization rates, while the utilization of capacity depends on the realization of demand shocks. Auernheimer and Trupkin (2013) find that regardless of the source and persistency of the shock, capital and labor inputs behave as complements. When demand shocks are temporary, inventory adjustment acts as a "shock absorber", which is negatively correlated with the rates of both capital and labor utilization. Introduction of inventory adjustment and variable capacity utilization into a standard macroeconomic model reveals the short-term substitutability between inventories and hours worked.

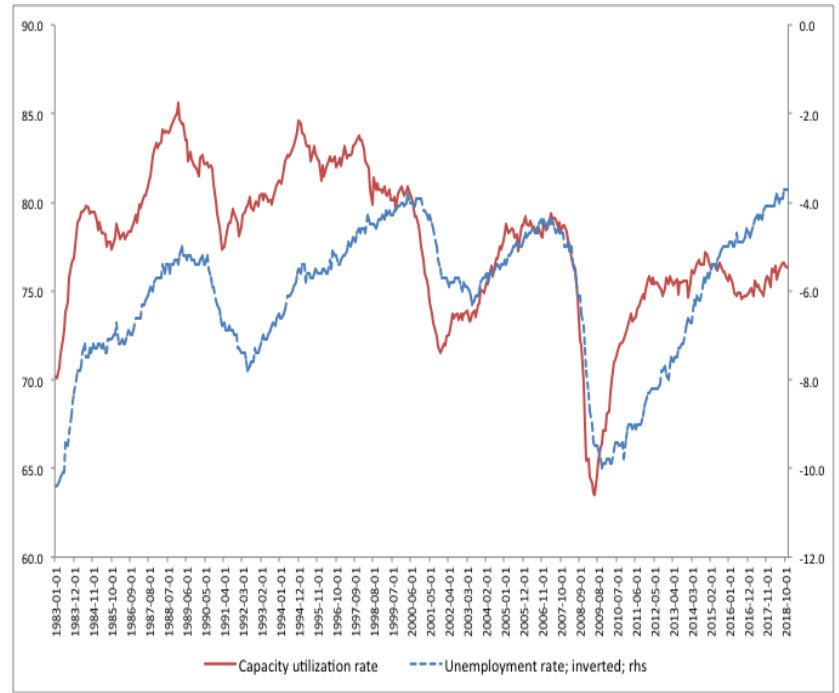

Figure 6. Capacity utilization and unemployment rates (1983M1 - 2018M11; in percent)

Sources: Federal Reserve Bank of St. Louis and the author.

Capacity utilization rate is the percentage of resources companies and factories use to produce output relative to the level that is feasible given the available resources. It provides an indication to the extent actual output deviates from the maximum output, defined as the highest level of output companies can sustain within the envelope of available resources. For instance, if capacity utilization rate is 75 percent, it means that another 25 percent of capacity could be made available for production (Note 10).

Capacity utilization rate may be defined as follows:

$$
y / y^{p}=f\left(n_{1}, n_{2}, \ldots, n_{K}\right) / f\left(n_{1}^{p}, n_{2}^{p}, \ldots, n_{K}^{p}\right)
$$

where $\mathrm{y}=$ actual level of output, $y^{p}=$ maximum available output given the resources and technology used in the production, and $n_{K}$ are $\mathrm{K}$ inputs used in the production. If $n_{1}$ denotes labor input, then $n_{1} / n_{1}^{p}$ is the ratio of 
underutilization of labor in production (relative to the maximum output). As $n_{1} / n_{1}^{p}$ falls, its conceptual counterpart, the rate of unemployment, will rise. Capacity utilization and unemployment rates (inverted) would therefore move in the same direction, given other conditions remain unchanged. When companies alter the combination of inputs used in the production, including by investing in new technology (e.g., by substituting between labor and machines), this could interfere with the parallel movements in capacity utilization and unemployment rates (Note 11).

At times capacity utilization and unemployment have provided inconsistent signals regarding the tightness of resource markets. For instance, in the second half of the 1990s, falling rate of unemployment pointed toward a tight labor market, while the utilization of existing capacity declined (Figure 6). This could have been caused by investment in new technology that raised capacity in manufacturing and led to a shift in the composition of resource use towards technically more advanced machines and equipment, thus increasing labor productivity. It may have lowered production costs and could have made it easier for companies to expand capacity. In the post-financial crisis period, we observe a similar trend (i.e., unemployment rate has declined sharply whereas capacity utilization rate has fluctuated in relatively narrow range since 2012).

The overall capacity utilization largely reflects the trend in the manufacturing sector (Figure 7). In the utilities sector the decline in capacity utilization is likely a secular phenomenon, reflecting transition from traditional energy sources (such as coal to generate electricity) to renewables (wind and solar power) which has made existing technologies to a large degree outdated. Mining sector has generally maintained higher rates of capacity utilization than the other sectors, although this has come with significant volatility. The growth of oil extraction using hydraulic fracturing helps explain partly these fluctuations.

In manufacturing, capacity utilization has not yet recovered and is still well below its highs during previous upswings. A low level of capacity utilization has been typically interpreted as a signal of weak output demand, but it could also suggests that companies are positioning themselves to manage resources more effectively without incurring higher production costs. This will be important in an environment where economic and policy uncertainties are significant, such as in the post-financial crisis period, and where competitive forces limit companies' ability to raise prices in response to higher costs. Furthermore, profitability of the corporate sector has remained high, which has supported higher equity prices. Corporate profits have fluctuated around $\$ 2.2$ trillion since 2012, which is more than 15 percent higher compared to the peak during the previous business cycle (recorded in the third quarter of 2006) (Note 12). High profitability could also point to improved efficiency.

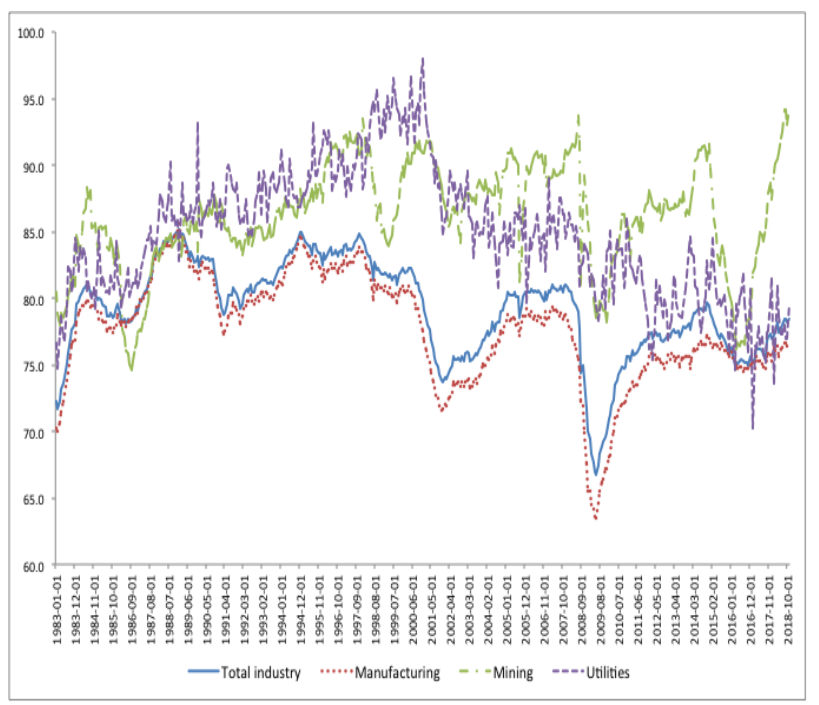

Figure 7. Capacity utilization rate by industry (1983M1 - 2018M11; in percent of potential capacity)

Sources: Federal Reserve Bank of St. Louis and the author.

Prior to the financial crisis, capacity utilization rates provided a reasonable good proxy for the resource utilization in the economy, consistent with other metrics (Figure 8). Movements in manufacturing capacity utilization and in the output gap were closely aligned. This close relationship appears to have broken down in the aftermath of the financial crisis. While capacity usage in manufacturing accelerated quickly following the crisis, it stalled in 2012 and since then has fluctuated in a relatively narrow range of 75-76 percent, which is well below levels that are typical for a mature 
business cycle. The output gap (and the unemployment rate, as shown in Figure 2), on the other hand, have moved continuously toward levels thought to be consistent with price stability. This kind of behavior suggests that companies are using capacity in a more strategic way to respond to new shocks, rather than aiming at full capacity usage.

When unemployment rate is low, elevated capacity utilization rate could aggravate labor cost pressures, as has occurred during most cyclical upswings since the 1960s, with the exception of mid-1990s when the high capacity utilization rate was combined with low employment rate and did not immediately result in the acceleration of cost pressures (Note 13). When companies face simultaneous labor and capacity constraints, these are more likely to result in cost increases as the production expands. On the other hand, when companies have idle capacity available to them, it is easier for them to respond to shocks affecting production without incurring additional costs. That helps alleviate cost and wage pressures, at least temporarily. However, the flexibility is limited, as the experience of the 1990s suggests. In the present tight labor market situation, therefore, the policymakers need to pay attention to the capacity utilization rate, which so far has remained low and possibly contributed to the gradual wage growth.

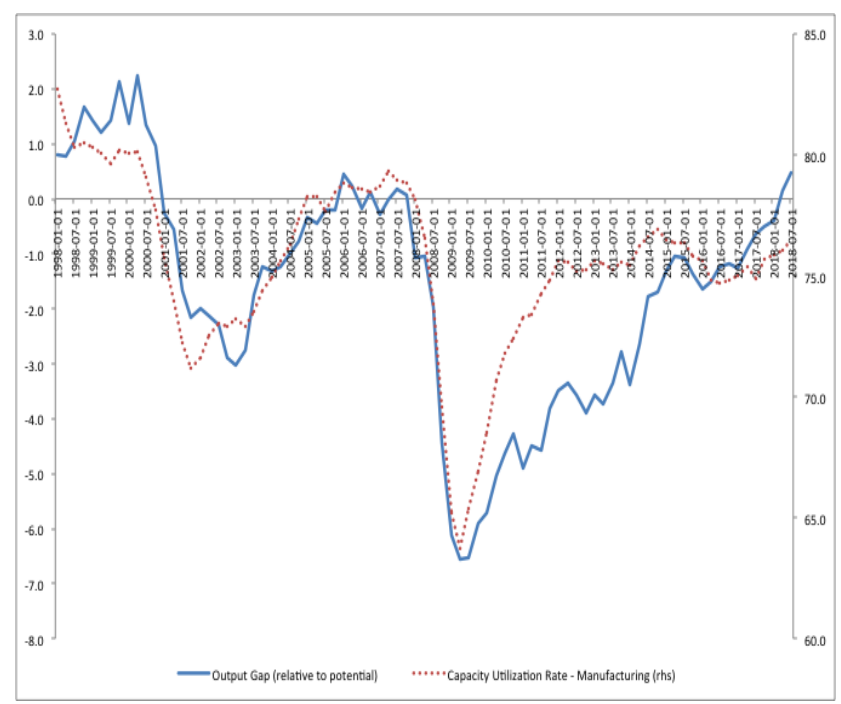

Figure 8. Capacity utilization rate and output gap 1998Q1 - 2018Q3

Sources: Federal Reserve Bank of St. Louis and the author.

To better understand the role of capacity utilization in resource management, it is important to recognize that firms vary their capacity utilization over time (Figure 9). That helps explain companies' investment behavior and why companies undertake larger, lumpy investments, which are not fully utilized but left idle. For instance, Backmann (2015) shows that companies adjust their capital stocks infrequently, but when they do, they tend to "overinvest". This allows firms to save in the fixed costs of capital and achieve an optimal level of capital services by adjusting the rate of utilization rather than the stock of capital (which is pre-determined in the short run). The rate of capacity utilization is correlated with the probability of capital investment (when existing capacity utilization rate is high, the likelihood of additional investment rises). Chatelain (2010) shows that the shortage of capital and financial constraints evolve at different pace when firms are allowed to vary their capacity utilization rates because investment acts as a stabilizer for capacity utilization. Furthermore, Gilchrist and Williams (2002) show that the optimal capital-to-labor ratio for new machines is increasing in the capacity utilization rate while the average variable cost increases as a function of the rate of capacity utilization, which in part depends on the age of machines. With idiosyncratic uncertainty, inefficient machines are scrapped early while efficient machines are used longer. Söderbom and Sato (2010) suggest that expected capacity utilization rate decreasing with an increase in uncertainty, again pointing to the desire to create buffers. In a recession, for instance, companies vary capacity utilization and tend to build larger capital stocks as uncertainty increases. See Greenwood, Hercowitz and Huffman (1988) and Mattey and Strongin (1997). 


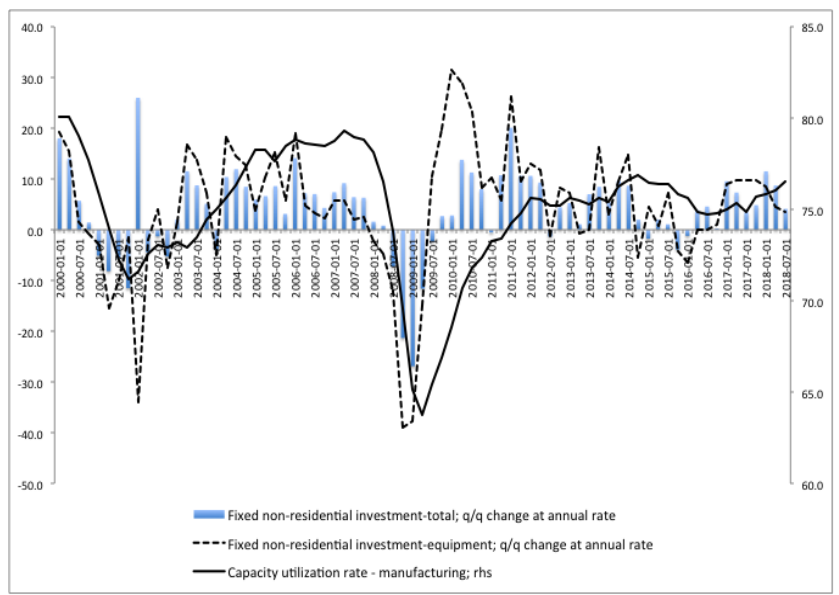

Figure 9. Capacity utilization rate and fixed, non-residential investments; total and equipment 2000Q1-2018Q3

(In percent)

Sources: Federal Reserve Bank of St. Louis and the author.

\section{Implications for Monetary Policy}

The Federal Reserve implements monetary policy to achieve maximum employment and price stability (i.e., inflation is expected to remain around 2 percent level over the medium term). Monetary policy is not set on a predetermined path as the Federal Open Market Committee (FOMC) adjusts the target range for the federal funds rate to reflect incoming data and changes in its economic outlook (Note 14).

Monetary policy formulation is frequently modeled using the Taylor rule (Taylor (1993)), or a variant of it. The Taylor rule links the policy interest rate to the natural (or neutral) interest rate (denoted by $\mathrm{r}^{*}$ ), as well as to the NAIRU (denoted by $\mathrm{u}^{*}$, or potential output, as in Taylor's original paper), which are not directly observable. The natural rate of interest is understood to be an interest rate, after adjusted for inflation, that is consistent with unemployment rate at its natural level while inflation remaining stable (Orphanides and Williams (2002)). Reflecting its importance for monetary policy formulation, the FOMC makes frequent references to the neutral (or natural) rate of interest in its policy statements, which is intended to provide a benchmark for the future policy rate path. In carrying out such a strategy, the policymakers are expected to have an accurate understanding of the level of the natural rate of interest at any point in time (the same applies to the natural rate of unemployment). Any misspecification in the natural rates of interest and unemployment, therefore, have the potential to lead to the misspecification of the federal funds rate target relative to what it ought to be if the natural rates were estimated accurately. This could risk the policymakers to tighten monetary policy too much, which could cause a recession. In the opposite situation, the Federal Reserve might allow monetary policy to remain too accommodative for too long, which could risk a runaway inflation (see Orphanides and Williams (2002) for a useful discussion on this issue).

Because of the inherent difficulty in accurately estimating the natural rates and the errors in these estimates, the policymakers are likely to adopt a gradual approach to monetary policy implementation, and tighten policy while looking for signs of getting closer to a 'neutral' policy stance. When policymakers are unable to accurately estimate the errors associated with the natural rates, Orphanides and Williams (2002) suggest that a strategy that is not influenced by misspecifications in the natural rates of interest and unemployment, would serve the policymakers better. Orphanides (2003) highlights that limited information complicates active monetary policy in managing inflation pressures, particularly due to the estimation of the output gap. See also Barsky, Justiniano and Melosi (2014), Laubach and Williams (2003), Holston, Laubach and Williams (2016), Lubic and Matthes (2015), Krustev (2018), Clarida (2018), and Carlstrom and Fuerst (2016).

Estimating the natural rate of interest accurately is therefore essential to minimize policy errors. Yellen (2016), for instance, argues that the policy interest rate at the end of the tightening cycle often exceeds the neutral interest rate. As a consequence, part of the reduction in the policy interest rate during a downturn reflects the unwinding of earlier tightening of monetary policy above the neutral rate of interest. This is an important observation and suggests that the Federal Reserve might have missed its longer-term interest rate anchor during earlier tightening episodes. It also underscores the practical difficulty in anchoring monetary policy to volatile estimates of the natural rate of interest. 
Koenig and Armen (2017) and Roberts (2018) suggest that the federal funds rate may still be below the estimated natural rate of interest, which argues for further tightening to reach a 'normal' monetary policy stance. Powell (2018) recently noted that interest rates remain below the broad range of estimates of the level that would be neutral for the economy. Furthermore, the policymakers have raised concerns that the current low level of the natural interest rate could complicate monetary policy implementation in the future if stabilizing inflation around the 2 percent goal in the current environment takes place at a level of the federal funds rate that is much lower than in the past (see Yellen, 2016).

Does capacity utilization improve the forecasting of inflation rate? The relation between capacity utilization and inflation rate is not robust since inflation is impacted by a multitude of factors and is shown to be more volatile than the rate of capacity utilization (Figure 10). Nevertheless, Franz and Gordon (1993), for instance, conclude that inflation is influenced by the rate of capacity utilization. Carner (1994) estimated that the stable-inflation rate of capacity utilization in the U.S. fluctuated around 80-82 percent (which remained remarkably stable from the 1960s until the early 1990s). Cecchetti (1995) and Emery and Chang (1997), however, suggest that capacity utilization, although adding value to the out-of-sample inflation forecasting, has become less informative for determining inflation. Dotsey and Stark (2005), with more recent data, resonate these findings and caution against relying too much on the rate of capacity utilization when forecasting U.S. inflation. See Corrado and Mattey (1997) and Gettings (1989).

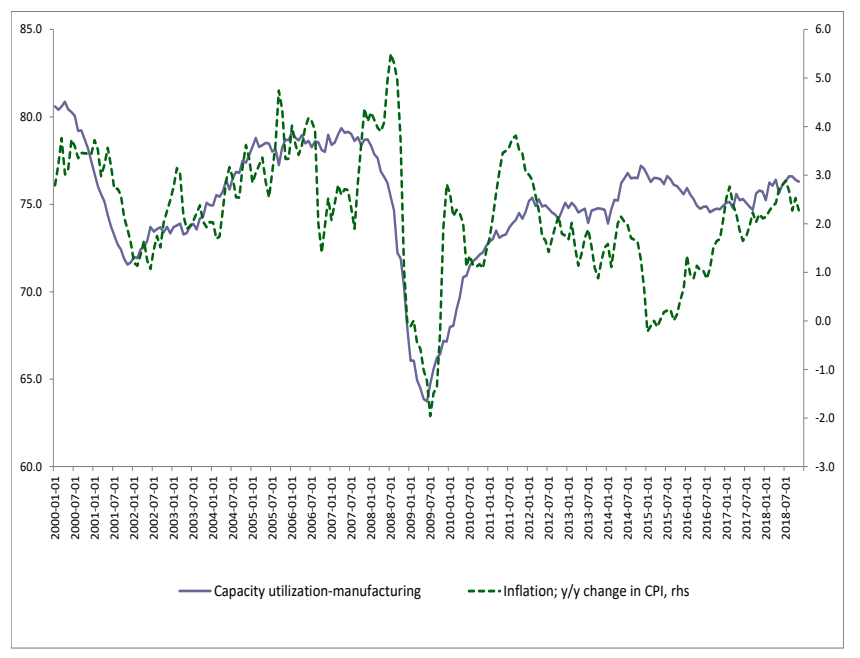

Figure 10. Capacity utilization and inflation 2000M1 - 2018M11 (In percent)

Sources: Federal Reserve Bank of St. Louis and the author.

Other studies have incorporated the rate of capacity utilization as an additional variable in the estimation in order to improve the quality of output gap forecasts. Alichi (2015) and Alichi et al. (2017) show that this enhances the accuracy of output gap estimates, particularly during periods when the unemployment and capacity utilization rates point to different outcomes for the slack in the economy, as is currently the case. Trimbur (2009) also finds that capacity utilization as an auxiliary indicator improves output gap estimates. See also Graff and Sturm (2010).

Figure 10 supports these findings and indicates that despite its volatility, movements in capacity utilization closely track changes in the consumer prices before the financial crisis. After the financial crisis the relationship has weakened. This underscores the need to understand the micro foundations of resource usage by corporation and how they are manifested in capacity utilization. Furthermore, the policymakers want to continue monitor a broad range of economic indicators when evaluating economic conditions and the sources of inflation pressures.

\section{Conclusions}

In this paper we analyze recent trends in the labor market. We point out that a number of indicators are in conflict with the tight labor market, including wage growth that has remained muted, vacancy duration rates that have stayed remarkable stable in certain sectors, and the rate of capacity utilization, which is currently historically low and significantly out of sync with other measures of resource utilization (e.g., output gap and unemployment rate). This leads us to conclude that there could be other forces in play to explain these trends. This paper contributes to the understanding of current wage and inflation developments in the context of a tight labor market, by suggesting that moderate wage and price pressures in part reflect the way corporations manage their resources. Capacity utilization can be viewed as a strategic parameter in the decision-making of corporations that permits firms to manage their resources more effectively. Slack in the production allows companies to organize their resources and manage production cost better even at times when labor market remains tight. A rapid pick-up in capacity utilization in the aftermath of the financial crisis illustrates its usefulness in managing production levels. We conclude that understanding the micro 
foundations of firms' operations management is likely to shed new light into the role of capacity utilization in the macroeconomic analysis. Available research shows that companies retain idle capacity even in the optimum, as a way to buffer against unexpected production shocks, which could help explain why labor costs have not risen faster and vacancy durations have remained remarkably stable, particularly in manufacturing and among larger companies, despite the tight labor market. In the services sector, firms experience more significant challenges in managing their resources because labor is usually the dominant input and companies' ability to offset labor costs through substitution is more limited, but this could change as automation and technological innovations help alleviate cost pressures.

We also review research in the relevant areas and show that capacity utilization has implications for capital investments. Whether or not rising capacity utilization would result in higher fixed business investment in structures and equipment in the near future and if capacity utilization would stabilize at the current post-financial crisis levels more permanent, remains to be seen. Studies suggest that technology increases flexible in operating manufacturing processes and encourages firms to increase the margin of excess capacity for the purpose to better handle demand shocks without moving onto the steeper-sloping portion of the marginal cost curve. This leads to lumpy investments. Further research in this area is clearly needed and economists have to rethink what drives the optimal capacity utilization rate and what rate is consistent with cyclical peaks during the business cycles. It is possible, therefore, that lower and more stable rates of capacity utilization would be the new "normal", if it represents companies' response to competitive pressures that limit wage and price increases, and if new technology makes it cheaper to maintain spare capacity to cushion against unexpected shocks.

Regarding monetary policy, we have underscored the need to monitor a broad range of indicators in assessing economic conditions and in formulating monetary policy. In the current environment where excessive wage and price pressures have not materialized despite historically low unemployment rates, capacity utilization could be informative in complementing other data for assessing the economy's potential and resource availability. Companies' increased ability to more effectively manage their resources through substitution, which reflects partly technological innovations taking place in the production process, as well as new ways to reach out to potential employees (e.g., through a variety of web-based search engines), could help alleviate cost and price pressures, despite the tight labor market. This could give the policymakers time to assess the current situation and halt raising the federal funds rate target range even if some inflation risk remains.

\section{Acknowledgement}

The author likes to thank the editor and three reviewers for their helpful comments and suggestions. All the remaining errors are the author's responsibility.

\section{Notes}

Note 1. Wage growth has picked up somewhat during 2018 and stood at 3.1 percent in November 2018, which is still modest by historical standards and in light of the tightness in the labor market.

Note 2. See, for instance, Board of Governors of the Federal Reserve System, Minutes of the Federal Open Market Committee (FOMC), November 7-8, 2018.

Note 3. While consumer price inflation averaged 4.8 percent in 1989 when unemployment rate reached its cyclical low, inflation only average 2.9 percent in 1996 (at the time, the Federal Reserve did not have an explicit, publicly announced, inflation target).

Note 4. Internet has revolutionized price competition and made price-discovery by ordinary consumers in any country easier and more efficient. Moreover, professional websites, such as www.Indeed.com and www.LinkedIn.com, which aim at enhancing interaction between employers and potential job seekers, are transforming the labor market and improving wage determination. Combined with the possibility to work remotely (not only locally but across national borders), the Internet has changed how the labor market operates. These developments could in part explain the current developments.

Note 5. Capacity utilization rate in manufacturing averaged 91.5 percent during May-June 1953, 87.2 percent from September 1968 to April 1969, and 80.9 percent in April 2000. Nominal wages grew by 7.7 percent, 6.8 percent and 3.6 percent, respectively, during these periods.

Note 6. The U.S. economy has added more than 20 million civilian jobs since bottoming out in December 2009, which shows the remarkable strength of the labor market. Consistent with this, other indicators, such as total quit and hire rates, are at or above the levels seen before the financial crisis.

Note 7. The Federal Reserve Bank of Kansas has developed a composite index comprising more than 20 labor market indicators, called the Labor Market Conditions Indicators (LMCI). The index measures the level of activity and it has stayed above its long-term trend since December 2015, which provides another indicator of labor market tightness. 
Note 8. In compiling the vacancy duration statistics, Saturday is included as a working day. The Federal Reserve Bank of St. Louis has discontinued these series (the latest data is for February/April 2018).

Note 9. Strengthening of the U.S. labor market has been broad based, affecting positively all education groups regardless of education level. Unemployment rate among workers with less than high school fell to 5.6 percent in November 2018, which is below its lowest point during the previous business cycle.

Note 10. Conceptually, capacity utilization rate has a parallel in the economy-wide output gap, which is the difference between actual and potential output.

Note 11. Substitution between labor and capital could impact labor productivity.

Note 12. Bachman (2016) notes that capacity utilization has declined across industries from the pre-crisis levels, for instance, in the "old" economy sectors, such as printing, wood products, and apparel and leather production. This suggests that there are also structural factors driving capacity utilization trends in addition to the cyclical components.

Note 13. In the first quarter of 1995, capacity utilization rate was 84.6 percent and unemployment rate was 5.5 percent. However, hourly earnings growth was only 2.5 percent, but accelerated in the second half of the 1990s as unemployment continued to fall further while capacity utilization stayed high.

Note 14. For instance, Board of Governors of the Federal Reserve System, Federal Open Market Committee (FOMC), Press Release, November 8, 2018.

\section{References}

Alichi, A., Bizimana, O., Laxton, D., Tanyeri, K., Wang, H., Yao, J., Z Zhang, F. (2017). Multivariate Filter Estimation of Potential Output for the United States. International Monetary Fund, Working Paper, WP/17/106. https://doi.org/10.5089/9781475598384.001

Alichi, A. (2015). A New Methodology for Estimating the Output Gap in the United States. International Monetary Fund, Working Paper, WP/15/144. https://doi.org/10.5089/9781513507569.001

Arntz, M., Gregory, T., \& Zierahn, U. (2016). The Risk of Automation for Jobs in OECD Countries. OECD Social, Employment and Migration Working Papers, No. 189.

Auernheimer, L., \& Trupkin, D. R. (2013). The Role of Inventories and Capacity Utilization as Shock Absorbers. Texas A\&M University and Universidad de Mnetevideo.

Bachman, D. (2016, June 21). The Curious Case of Manufacturing Capacity Utilization: Why Hasn't It Recovered from the Great Recession? Behind the Numbers. Deloitte, 1-9.

Bachmann, A. (2015). Lumpy Investment and Variable Capacity Utilization: Firm-Level and Macroeconomic Implications. Discussion Papers, Universität Bern, Department of Economics, No. 15-10.

Bansak, C., Morin, N., \& Sarr, M. (2004). Technology, Capital Spending, and Capacity Utilization. Federal Reserve Board, Washington, D.C.

Barsky, R., Justiniano, A., \& Mlosi, L. (2014). The Natural Rate and its Usefulness for Monetary Policy Making. American Economic Review, Papers and Proceedings, 104, 37-43. https://doi.org/10.1257/aer.104.5.37

Bean, C. (2006). Globalization and Inflation. Speech to the LSE Economic Society, London School of Economics.

Benzell, S. G., Kotlikoff, L. J., LaGarda, G., \& Schs, J. D. (2015). Robots Are Us: Some Economics of Human Replacement. National Bureau of Economic Research, Working Paper, 20941. https://doi.org/10.3386/w20941

Berriman, R., \& Hksworth, J. (2017, March) Will Robots Steal Our Jobs? The Potential Impact of Automation on the U.K. and Other Major Economies. PricewaterhouseCoopers, the U.K. Economic Outlook, 30-47, London, United Kingdom.

Bils, M., \& Cho, J. (1993). Cyclical Factor Utilization. University of Rochester and Queen's University.

Board of Governors of the Federal Reserve System. (2018, November 8). Federal Open Market Committee, Press Release.

Board of Governors of the Federal Reserve System. (2018, November 7-8). Minutes of the Federal Open Market Committee (FOMC).

Brynjolfsson, E., \& McAfee, A. (2015). Will Humans Go the Way of Horses? Labor in the Second Machine Age. Foreign Affairs, Council of Foreign Relations, 94(4), 8-14.

Calstrom, C. T., \& Fuerst, T. S. (2016). The Natural Rate of Interest in Taylor Rules. Economic Commentary, 2016-01, Federal Reserve Bank of Cleveland. 
Carner, A. C. (1994). Capacity Utilization and U.S. Inflation. Economic Review, Fourth Quarter, Federal Reserve Bank of Kansas City, 5-21.

Cecchetti, S. G. (1995). Inflation Indicators and Inflation Policy. Macroeconomic Annual, Vol. 10, 189-236, National Bureau of Economic Research. https://doi.org/10.1086/654274

Chatelain, J. (2010). Profit-Investment-Unemployment Nexus and Capacity Utilization in a Stock-Flow Consistent Model. Metroeconomica, 61(3), 454-472. https://doi.org/10.1111/j.1467-999X.2009.04074.x

Chui, M., Manyika, J., \& Mremadi, M. (2016). Where Machines Could Replace Humans - And Where They Can't (Yet). McKinsey Quarterly.

Clarida, R. H. (2018). Data Dependence and U.S. Monetary Policy. Remarks at the Clearing House and the Bank Policy Institute Annual Conference, New York, New York.

Corrado, C., \& Mttey, J. (1997). Capacity Utilization. Journal of Economic Perspectives, 11(1), 151-167. https://doi.org/10.1257/jep.11.1.151

Daly, M. C., \& Hobijn, B. (2017). Composition and Aggregate Real Wage Growth. American Economic Review, Papers and Proceedings, 107(5), 349-352. https://doi.org/10.1257/aer.p20171075

Daly, M. C, Hobijn, B., \& Pyle, B. (2016b). What's Up with Wage Growth? Economic Letter, March 7, 2016-07, Federal Reserve Bank of San Francisco, 1-5.

Daly, M. C., \& Hobijn, B. (2016a). The Intensive and Extensive Margins of Real Wage Adjustment. Federal Reserve Bank of San Francisco, Working Paper Series, 2016-04.

DHI Group, Inc. (DHI-DFH Mean Vacancy Duration Measure), retrieved from FRED, Federal Reserve Bank of St. Louis website (https://fred.stlouisfed.org/series).

Dotsey, M., \& Stark, T. (2005). Relationship Between Capacity Utilization and Inflation. Business Review, Second Quarter, Federal Reserve Bank of Philadelphia, 8-17.

Dufva, M., Halonen, M., Kari, M., Koivisto, T., Koivisto, R., \& Myllyoja, J. (2017). Kohti jaettua ymmärrystä työn tulevaisuudesta. Valtioneuvoston selvitys-ja tutkimustoiminnan julkaisusarja.

Emery, K. M., \& Chang, C. (1997). Is There a Stable Relationship between Capacity Utilization and Inflation? Economic Review, First Quarter, Federal Reserve Bank of Dallas, 14-20.

Erenburg, S. J. (1998). Productivity, Private and Public Capital, and Real Wage in the U.S. Applied Economics Letters, 5(8), 491-95. https://doi.org/10.1080/135048598354410

Fagnart, J., Licardro, O., \& Sneessens, H. (1995). Capacity Utilization Dynamics and Market Power. Universidad Carlos III de Madrid Working Paper, 95-15, Economics Series 10.

Federal Reserve Bank of St. Louis, FRED (retrieved from https://fred.stlouisfed.org/series).

Franz, W., \& Gordon, R. J. (1993). German and American Wage and Price Dynamics. European Economic Review, 37 (4), 719-754. https://doi.org/10.1016/0014-2921(93)90084-N

Frey, C. B., \& Osborne, M. A. (2013). The Future of Employment: How Susceptible Are Jobs to Computerization? University of Oxford.

Gettings, T. A. (1989). Capacity Utilization and Inflation. Economic Perspectives, Federal Reserve Bank of Chicago, 13(2), 2-9.

Ghayad, R., \& Dickens, W. (2012). What Can We Learn by Disaggregating the Unemployment-Vacancy Relationship?. Public Policy Brief, 12-3, Federal Reserve Bank of Boston. https://doi.org/10.2139/ssrn.2285075

Gilchrist, S., \& Williams, J. C. (2002). Investment, Capacity, and Uncertainty: A Putty-Clay Approach. Federal Reserve Bank of San Francisco, Working Paper, 2002-03.

Graff, M., \& Sturm, J. (2010). The Information Content of Capacity Utilization Rates for Output Gap Estimates. Presented at the Third International Seminar on Early Warning and Business Cycle Indicators, Moscow, Russian Federation.

Greenspan, A. (1997). Performance of the U.S. Economy. Testimony before the Committee on the Budget, United States Senate.

Greenwood, J., Hercowitz, Z., \& Huffman, G. W. (1988). Investment, Capacity Utilization, and the Real Business Cycle. American Economic Review, 78(3), 4102-417.

Guiseppe, B. (2014). Outsourcing and the Shift from Manufacturing to Services. VOX CEPR's Policy Portal. 
Holston, K., Laubach, T., \& Williams, J. C. (2016). Measuring the Natural Rate of Interest: International Trends and Determinants. Federal Reserve Bank of San Francisco, Working Paper Series, 2016-11.

International Monetary Fund. (2006, April). How Has Globalization Changed Inflation? World Economic Outlook, International Monetary Fund, 97-134.

Jakubovskis, A. (2017). Flexible Production Resources and Capacity Utilization Rates: A Robust Optimization Perspective. International Journal of Production Economics, 189, 77-85. https://doi.org/10.1016/j.ijpe.2017.03.011

Knotek, E. S. II. (2007). How Useful is Okun's Law? Economic Review, Fourth Quarter, Federal Reserve Bank of Kansas City, 73-103.

Koenig, E. F., \& Amen, Al. (2017). Navigating by the Stars: The Natural Rate as Economic Forecasting Tool. Federal Reserve Bank of Dallas, Economic Letter, 12(2), 2-4.

Kovanen, A. (2019). Perspectives From the Past for the Federal Reserve's Monetary Policy and Communication. International Journal of Financial Research, 10((2), 31-51. https://doi.org/10.5430/ijfr.v10n1p31

Krusell, P., Ohanian, L. E., Ríos-Rull, J., \& Violante, G. L. (2000). Capital-Skill Complementarity and Inequality: A Macroeconomic Analysis. Econometrica, 68(5), 1029-1053. https://doi.org/10.1111/1468-0262.00150

Krustev, G. (2018). The Natural Rate of Interest and the Financial Cycle. European Central Bank, Working Paper Series, No. 2168.

Lane, K., \& Rosewall, T. (2015). Firm-level Capacity Utilization and the Implications for Investment, Labor and Prices. Bulletin, December Quarter, Reserve Bank of Australia.

Laubach, T., \& Williams, J. C. (2003). Measuring the Natural Rate of Interest. Review of Economics and Statistics, 85(4), 1063-70. https://doi.org/10.1162/003465303772815934

Leduc, S., \& Wilson, D. J. (2017). Has the Wage Phillips Curve Gone Dormant? Economic Letter, Federal Reserve Bank of San Francisco, 2-5.

Lubic, T. A., \& Matthes, C. (2015). Calculating the Natural Rate of Interest: A Comparison of Two Alternative Approaches. Economic Brief, EB15-10, Federal Reserve Bank of Richmond.

Mattey, J.,\& Strongin, S. (1997). Factor Utilization and Margins for Adjusting Output: Evidence from Manufacturing Plants. Economic Review, Federal Reserve Bank of San Francisco, 2, 3-17.

Michaels, G.,\& Graetz, G. (2015). Estimating the Impact of Robots on Productivity and Employment. VOX, CEPR's Policy Portal.

Mokyr, J., Vickers, C., \& Ziebarth, N. L. (2015), The History of Technological Anxiety and the Future of Economic Growth: Is This Time Different? Journal of Economic Perspectives, 29 (3), 31-50. https://doi.org/10.1257/jep.29.3.31

Murphy, A. (2018). The Death of the Phillips Curve? Federal Reserve Bank of Dallas, Research Department, Working Paper, 1801.

Okun, A. M. (1962). Potential GNP: Its Measurement and Significance. American Statistical Association, Proceedings of the Business and Economics Statistics Section, 98-104.

Orphanides, A. (2003). The Quest for Prosperity Without Inflation. Journal of Monetary Economics, 50, 633-663. https://doi.org/10.1016/S0304-3932(03)00028-X

Orphanides, A., \& Williams, J. C. (2002). Robust Monetary Policy Rules with Unknown Natural Rates. Brookings Papers on Economic Activity, 2, 63-145. https://doi.org/10.1353/eca.2003.0007

Powell, J. H. (2018). The Federal Reserve's Framework for Monitoring Financial Stability. Remarks at the Economic Club of New York, New York.

Ravenna, F., \& Walsh, C. E. (2008). Vacancies, Unemployment, and the Phillips Curve. European Economic Review, 52(8), 1494-1521. https://doi.org/10.1016/j.euroecorev.2008.06.006

Roberts, J. M. (2018). An Estimate of the Long-Term Neutral Rate of Interest. FEDS Notes, Board of Governors of the Federal Reserve System, Washington, D.C.

Shapiro, M. D., Corrado, C., \& Clark, P. K. (1996). Macroeconomic Implications of Variation in the Workweek of Capital. Brookings Papers on Economic Activity, 2, 79-133. https://doi.org/10.2307/2534620

Söderbom, M., \& Sato, Y. (2010). Integration of Varying Capacity Utilization Into Dynamic Capital Theory. University of 
Gothenburg.

Staiger, D., Stock, J. H., \& Watson, M. W. (2001). Prices, Wages and the U.S. NAIRU in the 1990s. Princeton University.

Taylor, J. B. (1993). Discretion versus Policy Rules in Practice. Carnegie-Rochester Conference Series on Public Policy, 39, 195-214. https://doi.org/10.1016/0167-2231(93)90009-L

Trimbur, T. M. (2009). Improving Real-Time Estimates of the Output Gap. Federal Reserve Board, Finance and Economics Discussion Series, 2009-32, Washington D.C.

UBS (2016). Extreme Automation and Connectivity: The Global, Regional, and Investment Implications of the Fourth Industrial Revolution. UBS White Paper for the World Economic Forum, Annual Meeting 2016.

Violante, G. L. (2016). Skilled-Biased Technical Change. New York University.

West, D. M. (2015, October). What Happens If Robots Take the Jobs? The Impact of Emerging Technologies on Employment and Public Policy. Center for Technology Innovation, Brookings Institution.

Yellen, J. L. (2016). The Federal Reserve's Monetary Policy Toolkit: Past, Present, and Future. Remarks made at a symposium for "Designing Resilient Monetary Policy Framework for the Future", sponsored by the Federal Reserve Bank of Kansas City, Jackson Hole, Wyoming.

\section{Copyrights}

Copyright for this article is retained by the author(s), with first publication rights granted to the journal.

This is an open-access article distributed under the terms and conditions of the Creative Commons Attribution license which permits unrestricted use, distribution, and reproduction in any medium, provided the original work is properly cited. 